Article

\title{
Pilot-Scale Anaerobic Co-Digestion of the OFMSW: Improving Biogas Production and Startup
}

\author{
Constantin Stan ${ }^{1, *}$, Gerardo Collaguazo ${ }^{2}$, Constantin Streche ${ }^{1}$, Tiberiu Apostol ${ }^{1, *}$ and \\ Diana Mariana Cocarta ${ }^{1}$ (i) \\ 1 Department of Energy Production and Use, Faculty of Power Engineering, \\ University POLITEHNICA of Bucharest, Bucharest 060042, Romania; constantin_streche@yahoo.com (C.S.); \\ dmcocarta@gmail.com (D.M.C.) \\ 2 Faculty of Engineering in Applied Sciences, Technical University of the North, Ibarra 100150, Ecuador; \\ gicollaguazo@hotmail.es \\ * Correspondence: stan.constantin@yahoo.com (C.S.); tiberiuapostol80@gmail.com (T.A.); \\ Tel.: +40-727-030-863 (C.S.); +40-744-306-966 (T.A.)
}

Received: 26 April 2018; Accepted: 8 June 2018; Published: 10 June 2018

\begin{abstract}
This paper presents experimental results regarding anaerobic co-digestion of the organic fraction of municipal solid waste and fruit and vegetable waste in order to establish the efficiency of a $2 \mathrm{~m}^{3}$ volume pilot plant in terms of biogas and methane yield and stability of the process. The research study presents the feasibility of developing anaerobic digestion as an effective method for municipal solid waste management. The experiments were conducted in mesophilic conditions $\left(35{ }^{\circ} \mathrm{C}\right)$. Domestic waste water was used as inoculum. The results showed that the inoculum presence, temperature, and $\mathrm{pH}$ control, were essential in order to improve biogas production and its composition. Using liquid inoculum, the $\mathrm{CH}_{4}$ percentage in the biogas oscillated between $44 \%$ and $51 \%$, and the biogas production from 0.504 and $0.6 \mathrm{~m}^{3} /$ day. Compared to domestic waste water, animal manure increased the $\mathrm{CH}_{4}$ concentration in biogas (up to $63 \%$ ), while the daily biogas production increased by $26 \%$ and varied from 0.693 to $0.786 \mathrm{~m}^{3}$. The cumulative biogas production at the end of the experiments were $11.7 \mathrm{~m}^{3}$ and $15.89 \mathrm{~m}^{3}$, respectively. Using inoculum and co-digestion, the plant startup time was significantly reduced, the total solids content decreased from $22.7 \%$ to $19.8 \%$, while the volatile solids decreased from $37.6 \%$ to $31.2 \%$.
\end{abstract}

Keywords: biogas; OFMSW; anaerobic digestion; co-digestion; pilot-scale biogas plant

\section{Introduction}

Global warming and climate change represent one of the major environmental problems facing society today, mainly because of the dependency on the fossil fuel energy ( $88.4 \%$ out of the total energy consumed in 2015) [1,2]. The world urban population has grown approximately 5.6 times between 1950 and 2017 [3], having as a consequence the increase in quantities of waste generated. In 2017, it is estimated that 1.3 billion tons of municipal solid waste (MSW) are generated at the global level $[4,5]$, contributing to the current environmental problems. Therefore, this requires both the diversification of renewable energy resources and proper management of MSW so as to reduce their negative impact on the environment. This is the answer to the current policies and regulations regarding the targets for greenhouse gas emissions reduction, alternative solutions for conventional energy, waste generation reduction, and energy recovery from the municipal waste [6-9].

Improper MSW management contributes to negative effects on the environment and human health [10], and hence policies and stringent national and international regulations are provided $[8,10,11]$ that require organic fraction MSW (OFMSW) reduction in landfilling and energy recovery [9]. 
Due to the heterogeneous and different sizes of MSW, it is very difficult to do/deal with the physico-chemical characterization [4,5].

Generally, the biodegradable fraction of the MSW (i.e., food and biomass residues, paper, and cardboard) varies between $30 \%$ and $65 \%$ [4,5,11]. In this respect, different research [12-19] shows that MSWs are a potential primary energy source, especially the organic fraction of the municipal solid waste (i.e., OFMSW) by the amount of biogas that can be produced through anaerobic digestion (AD). Therefore, $\mathrm{AD}$ is seen as a proper waste management solution in terms of solving the problem of waste generation and renewable energy production [20-22].

Anaerobic digestion is a microbiological process of organic matter decomposition in the absence of air. The key process phases of AD are as follows: (1) hydrolysis, in which the complex organic molecules are converted into simple sugars, fatty acids, amino acids, and water; (2) acidogenesis, where the molecules from the previous stage are broken into organic acids, ammonia, hydrogen sulfide, and carbon dioxide; (3) acetogenesis, in which hydrogen and carbon dioxide are converted into acetic acid; and (4) methanogenesis, the final stage of $\mathrm{AD}$, when the intermediate products of the preceding stages are converted into methane, carbon dioxide, and water [23]. Different research studies [24-30] showed that both anaerobic digestion and biogas production are influenced by some physical and chemical parameters such as the total solids content (TS), the volatile solids content (VS), the carbon and nitrogen ratio $(\mathrm{C} / \mathrm{N})$, the particle size, the temperature and $\mathrm{pH}$, the inoculum type, and the co-digestion with other organic wastes (i.e., animal manure, sewage sludge, waste from food industry).

Anaerobic digestion has been generally used for the anaerobic treatment of one type of substrate, but in recent years, researchers have demonstrated that $\mathrm{AD}$ becomes more stable when using multiple types of organic waste [15,31-39]. This has been presented in several studies on the anaerobic co-digestion of the OFMSW mixed with other wastes, for example OFMSW with sewage sludge; OFMSW with agricultural residues; and OFMSW with animal manure [12-15,25,37,40-45]. An important aspect to take into account concerning the anaerobic co-digestion is the total $\mathrm{C} / \mathrm{N}$ ratio from the substrate composition. Anaerobic digestion is developing under favorable conditions when $\mathrm{C} / \mathrm{N}$ is between 20:1-30:1 [18,20,37]. Fruits and vegetable wastes (FVWs) represent an important residue because they are produced in very big amounts in agricultural activities and supermarkets. Their generation increases the final operational costs of markets due to sales losses and disposal costs [46]. The co-digestion of the OFMSW and FVW with animal manure represents an option for controlling the AD stability process and maximizing biogas production $[46,47]$. Both residues can be used as an energy source meeting the specification of European Parliament legislation (Directive 2008/98/CE), which establishes that disposal in ecological landfills must be the direction only for the residues which cannot be recycled, reused or recovered [48].

This paper's main objective is to evaluate the performance of an anaerobic digestion pilot plant for biogas production, based on the OFMSW and FVW in co-digestion with other organic substances as an activator of methanogenesis processes. In this study, the following characteristics were assessed: the reactor start-up time, the optimization of the biogas production, and composition and the OFMSW biodegradability based on the TS and VS reduction, since the VS is the organic part of the TS that is transformed into biogas [21]. Biogas production is mainly influenced by the distribution of the TS and VS [22-24]. The experimental setup is placed in the Laboratory of Environmental Monitoring and Certification of the Energy Potential of Waste from the Faculty of Power Engineering, from the University POLITEHNICA of Bucharest.

Additionally, the paper presents statistical data regarding the waste management in Romania and Ecuador in order to estimate the potential of biogas production and to establish the feasibility of developing $\mathrm{AD}$ as an effective method for municipal solid waste management in these countries and also other countries that have similar waste composition. Thus, one preliminary test and two different experiments were conducted: mono and co-digestion of OFMSW and FVW with other organic waste and animal manure. The process was assessed with and without inoculum as domestic wastewater. 


\section{Overview of Municipal Solid Waste Management in Romania and Ecuador}

An efficient integrated waste management solution involves different steps such as separate collection, transport, recycling, and landfilling with monitoring of the landfill sites after closure. The waste management responsibility goes to local public administrations. Even though there are differences in the social and economic climate between Romania and Ecuador, they present a similarity in terms of MSW generation, composition, and management [11,13,14,37], with some exceptions corresponding to the Romanian economic crisis between 2007 and 2010 (Figure 1).

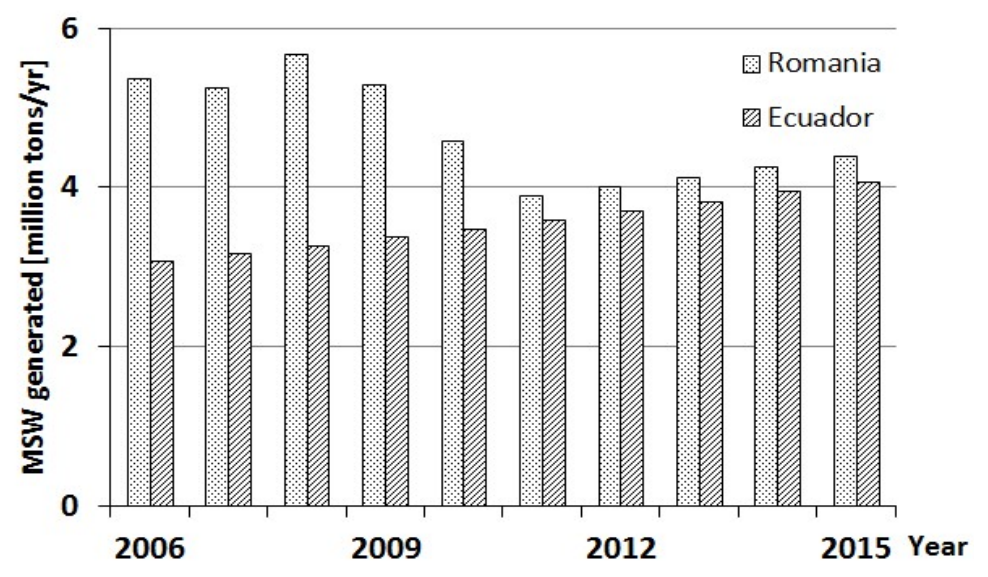

Figure 1. Municipal solid waste (MSW) generation in Romania and Ecuador.

In terms of MSW production, Romanian statistics show that each person generated, on average, $0.9 \mathrm{~kg} /$ day of waste in urban areas and $0.5 \mathrm{~kg} /$ day of waste in rural areas. In 2015, in Romania, the MSW annual generation rate was 4.38 million tons of waste. About $73.5 \%$ from the total waste generation was landfilled, $13.11 \%$ was recycled, and $13.39 \%$ was recovered and treated by other methods [11,12]. In Ecuador, 4.06 million tons of municipal solid waste was generated in 2015, with a waste generation rate of $0.7 \mathrm{~kg} / \mathrm{per}$ capita/day. From the total waste generation, $68 \%$ was landfilled, $18 \%$ was composed, $12 \%$ was recycled, and $2 \%$ was submitted to other treatments [37]. Accordingly, in both countries the most used treatment solution for MSW remains landfilling, which is no longer an actual and sustainable solution. Figure 2 presents the similarities between the MSW medium composition in Romania and Ecuador [11,12,37].

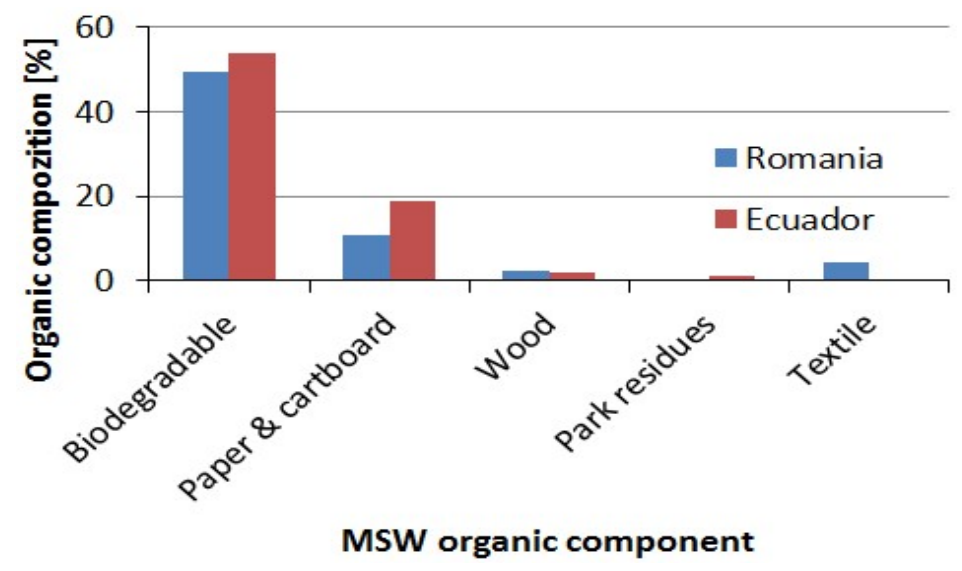

Figure 2. MSW organic composition.

The difference between the organic fraction of the MSW from Romania and Ecuador is almost $10 \%$, which can be explained by the different lifestyles of the populations from these countries. The high 
content of the biodegradable fraction contributes to a good potential for biogas production. Knowing that biogas production is between $80-160 \mathrm{~m}^{3}$ biogas/t of waste [21], the anaerobic digestion of the OFMSW as a method of MSW treatment is an attractive choice for both countries.

\section{Materials and Methods}

\subsection{Substrates and Inoculum}

The quantity and quality of the substrate is the main factor influencing the production and biogas composition $[20,33]$.

In the framework of the experimental study, OFMSW and FVW were used as substrates. The OFMSW was collected from a local food market. It was basically composed of raw food waste: cabbage, potatoes, tomatoes, and cucumber. Fruit and vegetable waste was collected from the fresh product department of a supermarket. The mixture of fruits that was used is composed of apples $(25 \%)$, pears $(25 \%)$, bananas $(10 \%)$, plums $(15 \%)$, apricots $(15 \%)$, and peaches $(10 \%)$. Additionally, dry grass and green corn stalks were used. After the collection process, the OFMSW and FVW were ground in order to reduce particles size.

The considered liquid inoculum is made up of domestic wastewater, animal manure, and organic waste. The used inoculum had a high $\mathrm{pH}$ indicating high buffering capacity. The buffering contributed to maintaining $\mathrm{pH}$ in an adequate range, refraining the accumulation of volatile fatty acids, which occurs often during the digestion of OFMSW that contains high amounts of food waste [49]. The characteristics of substrate and inoculum are presented in Table 1.

Table 1. Characteristics and feeding conditions of substrate and inoculum used in the framework of the study.

\begin{tabular}{cccccccc}
\hline Waste & Weight W [kg] & Percentage [\%] & Moisture H [\%] & TS [\%] & VS [\% (VS/TS)] & pH & C/N \\
\hline OFMSW & 102 & 35.8 & 82.4 & 17.6 & 82.7 & 6.3 & 19 \\
Fruits & 40 & 13.7 & 92.1 & 7.9 & 87.1 & 6.6 & 37 \\
Potatoes & 30 & 10.2 & 84.1 & 15.9 & 85.4 & 5.9 & 34 \\
Dry grass & 6 & 2.0 & 24.6 & 76.4 & 81.6 & 7.2 & 12 \\
Green corn stalks & 35 & 11.9 & 77.3 & 12.7 & 75.3 & 6.1 & 26 \\
Beef manure & 40 & 13.7 & 72.6 & 27.4 & 73.8 & 6.3 & 18 \\
Pig manure & 40 & 13.7 & 73.2 & 26.8 & 74.3 & 7.3 & 12 \\
\hline Total & $\mathbf{2 9 3}$ & $\mathbf{1 0 0}$ & $\mathbf{7 9 . 5 1 *}$ & $\mathbf{2 0 . 4 9}$ & $\mathbf{7 9 . 1 7}$ & $\mathbf{6 . 4 9}^{*}$ & $\mathbf{2 2 . 7 8}^{*}$ \\
\hline
\end{tabular}

${ }^{*}$ weighted average values. OFMSW = organic fraction of municipal solid waste; TS = total solids; VS = volatile solids; $\mathrm{C} / \mathrm{N}=$ carbon and nitrogen ration.

Because of the high moisture content (83.2\%), no added water was necessary for the AD process. As inoculum for the AD process, an optimized amount of 30 liters of domestic wastewater from a septic tank were used.

The presented research approach was taken as different studies [35-38] have shown that anaerobic co-digestion with different organic substrates (e.g., municipal wastewater treatment sludge and fat, oil, and grease; food waste with tall fescue; pig slurry with maize cob, etc.) has improved the AD process in terms of biogas production and composition.

\subsection{Analytical Methods}

The characteristics of the substrate and inoculum contribute to the determination of parameters such as the humidity, TS content, VS content, $\mathrm{pH}$, and $\mathrm{C} / \mathrm{N}$ ratio. To identify the humidity, TS, and VS, the thermogravimetric method was used. The $\mathrm{pH}$ was measured using a digital measuring device with combine electrode, type IQ SENSOR NET System 2020 XT. The humidity was measured with specific equipment, an electric heated oven, type Nitech SLW53ECO. TS and VS were measured with a calcination oven Nabertherm L9/11/SW type. By an elemental analyzer, Euro EA3000 type, the C/N ratio was measured. 
The biogas composition was determined by means of a Dräger X-am 5600 gas analyzer type, which uses infrared technology to determine $\mathrm{CH}_{4}$ and $\mathrm{CO}_{2}$ and electrochemical sensors to determine $\mathrm{O}_{2}$ and $\mathrm{H}_{2} \mathrm{~S}$.

For the experimental study, a quantity of $80 \mathrm{~kg}$ of inoculum (i.e., animal livestock manure from pigs and cows) was used. The ratio of inoculum TS/substrate was $36.1 \%$, which is in accordance with data from the literature specifying $30-50 \%$ [14,39]. The OFMSW/other organic wastes ratio is 1:1. In this way, we were able to evaluate the influence of the different parameters on the pilot plant performance. The total load of the reactor was $293 \mathrm{~kg}$.

As shown in Table 1, the organic substrate had a high content of VS (79.17\% of total solids), and consequently it had a high biogas production potential. Additionally, the $\mathrm{C} / \mathrm{N}$ ratio was about 23 and a high moisture content of $79.5 \%$ increases the $\mathrm{AD}$ process efficiency.

On the other hand, the pretreatment of the OFMSW in co-digestion with other organic wastes consisted in particle size reduction by shredding at $4-12 \mathrm{~mm}$, so that the degradation of the organic matter could be conducted under proper conditions [14,21,25].

\subsection{Pilot-Scale Startup and Operation}

The experiments were conducted using an anaerobic digestion pilot plant that was built according to a proper design. The vertical pilot plant was a dry anaerobic digester in one stage with a volume of $2 \mathrm{~m}^{3}$ with mixing and recirculation of the leachate (Figure 3). The dry process was used based on the literature data regarding the advantages of the wet $\mathrm{AD}$, such as simple systems, which are easier to maintain because they do not require complex equipment (e.g., pumps, stirring systems, substrate feed in systems) [18-20].
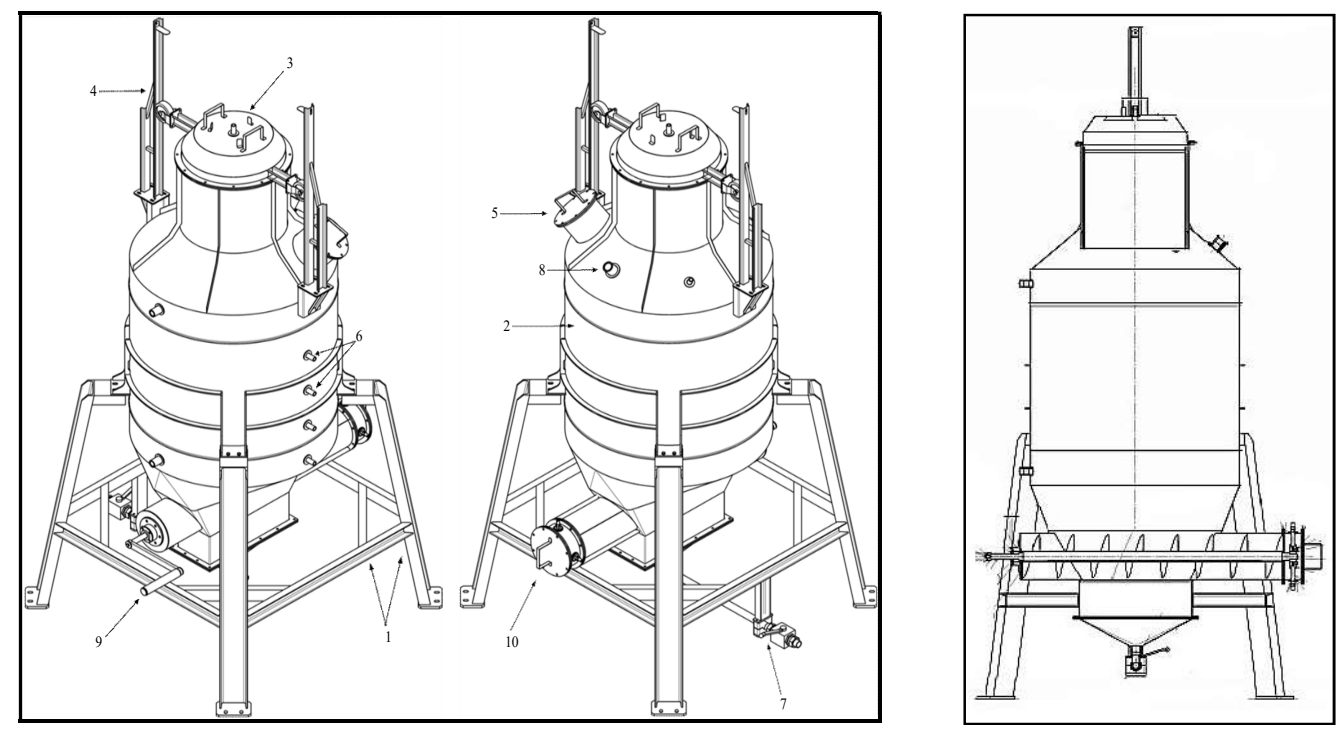

Figure 3. Isometric view of the pilot plant used for the neutralization/stabilization of OFMSW.

The pilot plant is flexible in use in terms of the process temperature control, and it can operate at mesophilic $\left(35^{\circ} \mathrm{C}\right)$ or thermophilic $\left(55^{\circ} \mathrm{C}\right)$ conditions due to the thermal insulation with mineral wood and the electrical heating thermostatic system arranged on the entire surface of the digester for operation in cold seasons.

The reactor was operated under mesophilic conditions at $35^{\circ} \mathrm{C} \pm 2{ }^{\circ} \mathrm{C}$. The process temperature can be automatically controlled, and the inside temperature is continuously monitored by means of temperature sensors connected to a Thermocouple Data Logger with LCD Display and USB Interface.

The main components of the pilot plant were: (1) mechanical resistance system of the plant (pilot plant support); (2) AD reactor; (3) mobile biogas capture and measuring system; (4) guidance 
structure of biogas capture and measurement system; (5) feeding system; (6) temperature sensors; (7) leachate collection and recirculation system; (8) biogas sampling; (9) digestate discharge system (crank driving a screw conveyor); and (10) discharge flange.

The pilot plant could be loaded with size particles in the range of $30-50 \mathrm{~mm}$, and on the bottom of the plant was the leachate collection and recycling system. Due to this system, the proper conditions for the homogeneous distribution of the microorganisms responsible for the decomposition of organic matter were maintained. The biogas composition and quantity were periodically monitored ( 3 to 5 times/day).

The daily biogas volume, in $\mathrm{m}^{3}$, was determined by measuring the vertical movement of the reactor top (Figure 4) based on the biogas pressure inside the reactor.
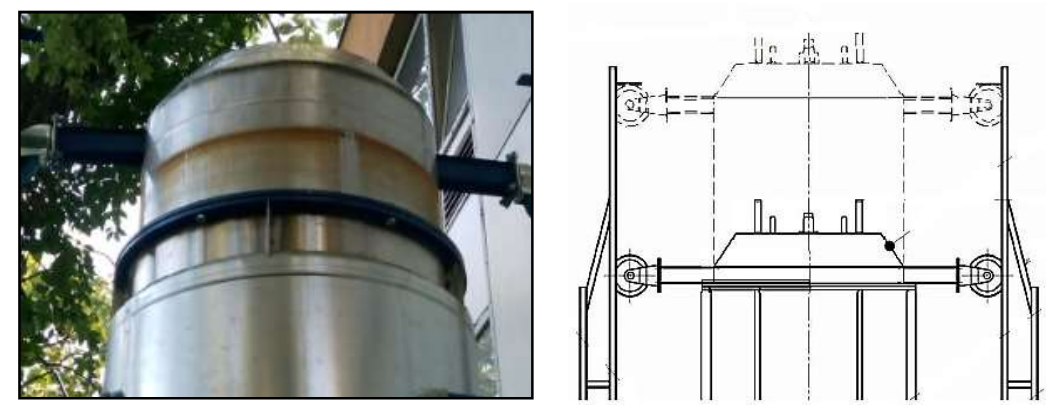

Figure 4. Float cover assembly.

The biogas production was estimated using Equation (1):

$$
V_{B G}=\pi r^{2} h
$$

\subsection{Experimental Conditions}

\subsubsection{Experiment No. 1}

This preliminary experiment was aimed at highlighting the importance of the inoculum in biogas production and to test, according to the time parameter, and whether the absence of inoculum may lead to biogas formation mainly due to the biodegradability of the substrate used (high content of VS). Therefore, the first material used in this experiment was $150 \mathrm{~kg}$ of OFMSW composed of raw food waste: cabbage, potatoes, tomatoes, and cucumbers. The batch experiments were conducted for a hydraulic retention time (HRT) of 21 days, and the temperature varied between $26.5^{\circ} \mathrm{C}$ and $39.5^{\circ} \mathrm{C}$; the average temperature was of $34{ }^{\circ} \mathrm{C}$ to maintain the mesophilic conditions $[13,21,33]$.

\subsubsection{Experiment No. 2}

In this experimental set-up inoculum was used, and an extra $48 \mathrm{~kg}$ of OFMSW sorted at the source was added to the reactor filled with the previous substrate experimental test. For inoculum, we used 30 liters of domestic wastewater from a septic tank. The batch experiment was conducted for an HRT of 30 days at mesophilic temperature with continuous parameter monitoring to observe the influence of the temperature and $\mathrm{pH}$ on biogas production $[15,17,20,21,40,45,46,50-53]$. The reactor operated under mesophilic conditions with leachate recirculation. The biogas production was measured from 3 to 5 times per day based on the quantity of the resulting biogas.

\subsubsection{Experiment No. 3}

For this batch experimental test, the digester was fed with fresh $293 \mathrm{~kg}$ of organic substrate, comprised of the following: OFMSW and FVW, dry grass, green corn stalks, and animal manure. The composition and physico-chemical characterization is presented in Table 1. 
The retention time was of 31 days, and the reactor operated under mesophilic conditions and leachate recirculation.

\section{Results and Discussion}

\subsection{Biogas Production}

In the first experiment test, due to the absence of inoculum, the $\mathrm{pH}$ value varied around 6.3 and required daily value correction by adding leachate calcium hydroxide (lime). The $\mathrm{pH}$ was stabilized at 6.7 after a period of 16 days, indicating the possibility of the beginning of the methanogenesis phase $[13,34]$.

After seven days from the plant startup, a gaseous emission was measured, being composed of $\mathrm{CO}_{2}, \mathrm{H}_{2} \mathrm{~S}$, and $\mathrm{O}_{2}$. On day 14 , the $\mathrm{CO}_{2}$ was $92 \%$, while the concentration of $\mathrm{O}_{2}$ was $8 \%$, which was inhibitive for microorganism formation. On the 18th day, the $\mathrm{CH}_{4}$ measured in the gas composition was only $8 \%$. After this, the gas production mainly consisted of $\mathrm{CO}_{2}$ and rapidly decreased in time.

Therefore, in the first experimental test of the AD of the OFMSW without inoculum, the production of biogas was very low. Only gas containing $\mathrm{CO}_{2}$ and other traces (i.e., $\mathrm{H}_{2} \mathrm{~S}$ and $\mathrm{O}_{2}$ ) was obtained with low $\mathrm{CH}_{4}$ content and noncombustible. The methanogenesis phase did not develop in appropriate conditions, due to the absence of the inoculum, and a low $\mathrm{pH}$ (up to 6.7) was obtained. This generated an acid environment that inhibited the formation and growth of methanogenic bacteria. This fact has also been noticed in other scientific research $[17,36,38,39,41-44,54]$. Under these conditions, on day 21 we decided to stop the experiment.

Using the substrate accumulated in the first experiment, liquid inoculum was added to the installation. The temperature variation throughout the second experimental test varied from $29.5^{\circ} \mathrm{C}$ to $37^{\circ} \mathrm{C}$, with a medium temperature of $33.7^{\circ} \mathrm{C}$ (Figure 5), while the $\mathrm{pH}$ varied from 6.1 to 7.4 (Figure 6).

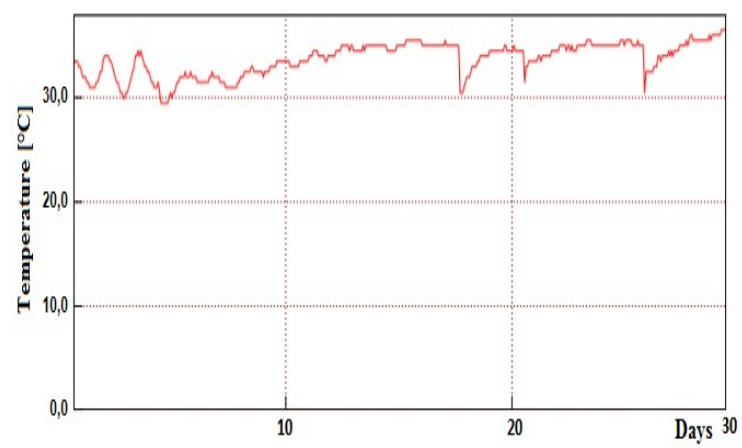

Figure 5. Experiment No. 2: temperature variation with time.

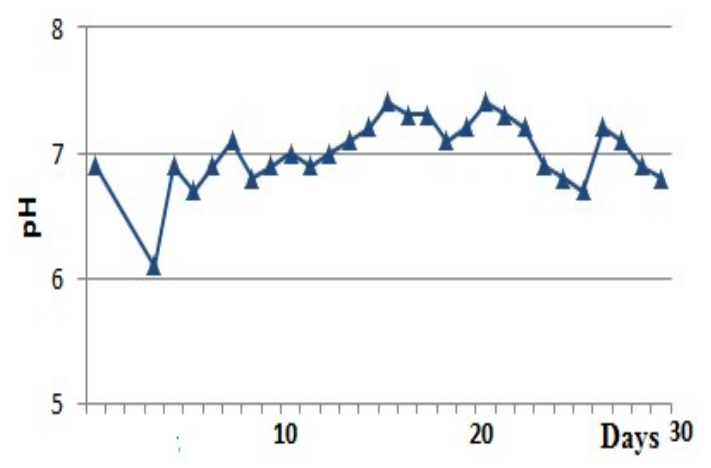

Figure 6. Experiment No. 2: $\mathrm{pH}$ variation with time. 
In the first four days of the test, the $\mathrm{pH}$ encountered a decrease from 6.9 to 6.1 , indicating that the process was under acid phase. The methanogenesis phase began after five days from the reactor loading. The $\mathrm{pH}$ in this phase was constant, around the value of 7.04. For the process stabilization, the $\mathrm{pH}$ value was maintained at 7.7 by adding $3-5 \mathrm{~g}$ of calcium hydroxide (lime) per liter of leachate. To maintain the conditions necessary for a homogeneous distribution of the micro-organisms responsible for organic matter decomposition, the leachate was recirculated periodically: every three hours from the top of the plant by spraying.

The quality of the biogas was quantified in terms of $\mathrm{CH}_{4}$ percentage. The cumulative biogas and $\mathrm{CH}_{4}$ production, in $\mathrm{m}^{3}$, was determined by summing the daily values. The obtained results are illustrated in Figure 7.

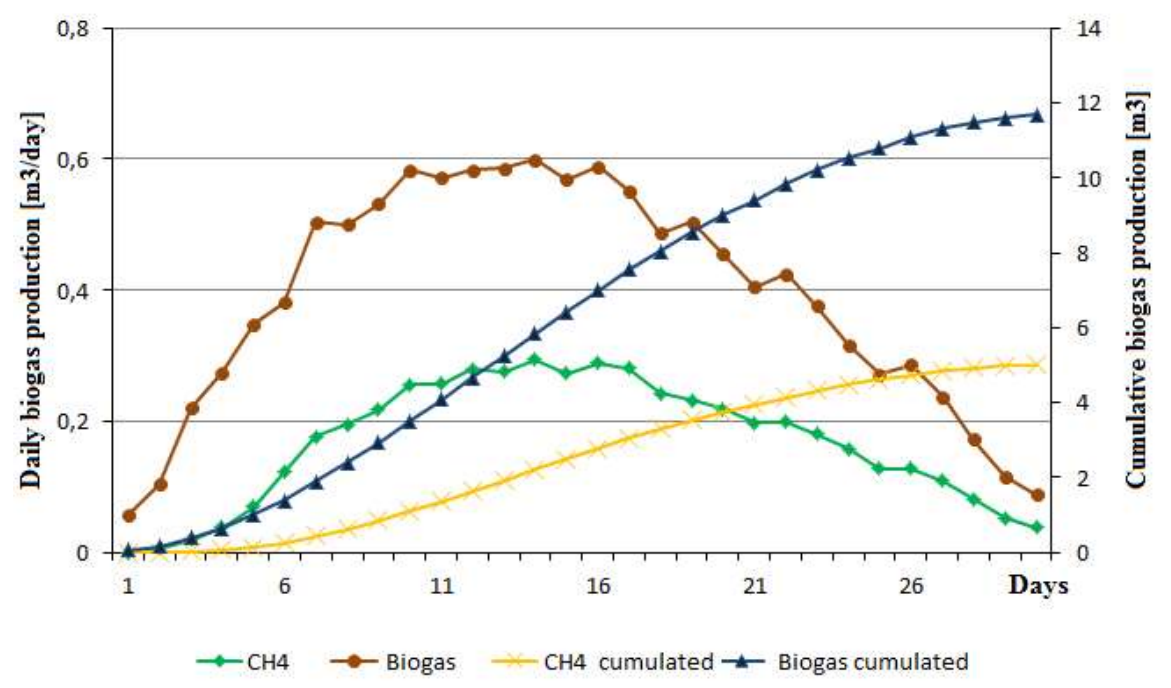

Figure 7. Experiment No. 2: daily and cumulative biogas and $\mathrm{CH}_{4}$ production.

Across the experimental activities it was observed that the daily production of biogas increased rapidly in the first 10 days of the digester loading, reaching a value of $0.58 \mathrm{~m}^{3}$. Between days 7-19, the biogas production varied between 0.5 and $0.6 \mathrm{~m}^{3} /$ day. The average biogas production during this period was of $0.58 \mathrm{~m}^{3} /$ day $\left(0.261 \mathrm{~m}^{3}\right.$ of $\mathrm{CH}_{4}$ per day). The maximum production of biogas $\left(0.6 \mathrm{~m}^{3}\right.$ /day) was recorded on day 14 . After day 19 , until the end of the experiment, the biogas production started to drop, reaching a minimum of $0.087 \mathrm{~m}^{3} /$ day on day 30 .

The cumulative production of $\mathrm{CH}_{4}$ after the 30 days of the experimental study was of approximately $5.02 \mathrm{~m}^{3} \mathrm{CH}_{4}$. The quantity of biogas that can be produced per ton of waste is equivalent to about $59.1 \mathrm{~m}^{3}$ biogas $\left(25.35 \mathrm{~m}^{3} \mathrm{CH}_{4}\right)$. The specific $\mathrm{CH}_{4}$ production in relation to the VS, considering the information from Table 1 , is about $0.172 \mathrm{~m}^{3} \mathrm{CH}_{4} / \mathrm{kg}_{-} \mathrm{VS}\left(0.40 \mathrm{~m}^{3}\right.$ biogas $\left./ \mathrm{kg}_{-} \mathrm{Vs}\right)$. The experimental results are comparable to those reported in the scientific literature. Thus, Pavi S. et al. [21], K. D. Monson et al. [26], J. Rapport et al. [27] reported that at an industrial level the specific biogas production is between $80-120 \mathrm{~m}^{3} /$ tons of waste.

Other studies such as Mao et al. [55] and Velmurugan et al. [56] showed that the specific production of methane at a mesophilic and retention time (HRT) of 28 to 60 days, is between 0.2 and $0.477 \mathrm{~m}^{3}$ $\mathrm{CH}_{4} / \mathrm{kg}_{\text {-VS }}$ for the OFMSW sorted at the source. On the other hand, Li et al. [46] and Velmurugan and Ramanujan [56] demonstrated that the specific production of biogas from vegetable waste is $0.387 \mathrm{~m}^{3}$ biogas $/ \mathrm{kg}_{\text {_VS }}$ at mesophilic temperature and an HRT of 30 days. The differences can be explained by the fact that the experiments with the pilot plant took place outside. Consequently, there are high temperature variations, in particular during the night. Additionally, the data reported by the scientific research mentioned above refers to longer periods of study (30-60 days).

The digestate resulting from the test was analyzed in terms of TS and VS. The obtained results showed a decrease of $19.8 \%$ and $31.2 \%$, respectively, compared to the preliminary experiment 
when inoculum was not used. Other studies, such as Forster-Carneiro et al. [57], showed that on thermophilic temperature using OFMSW sorted at the source, the TS and VS was reduced by $34.7 \%$ and $44.2 \%$, respectively, for an HRT of 60 days. Also, Soavcool et al. [44] and Li et al. [54] reported a decrease of $41.8 \%$ of the VS at $30{ }^{\circ} \mathrm{C}$ mesophilic conditions and an HRT of 60 days. The difference that exists between the degradability is due to the temperatures and the higher HRT used in the studies mentioned.

From the experiments, we observed that the use of inoculum improved the AD process by reducing the starting time for the acidogenesis phase and that biogas production was accelerated.

In the third experiment, the temperature varied from $28.5^{\circ} \mathrm{C}$ to $38^{\circ} \mathrm{C}$ with an average temperature of $33.8^{\circ} \mathrm{C}$ (Figure 8 ), while the $\mathrm{pH}$ varied between 5.9 and 6.9 , after correction by adding calcium hydroxide (lime) (Figure 9).

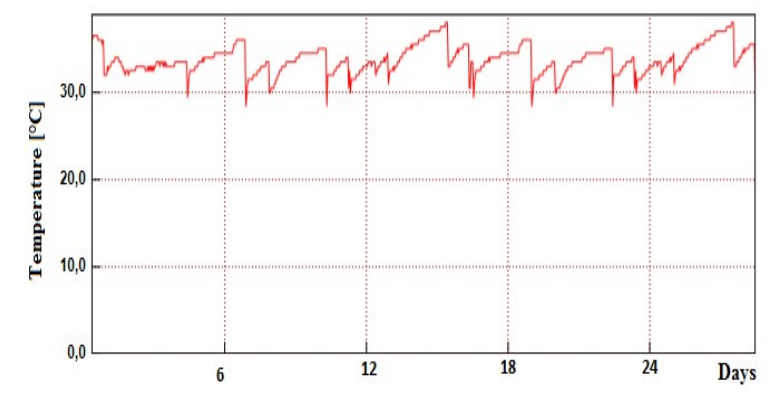

Figure 8. Experiment No. 3: temperature variation with time.

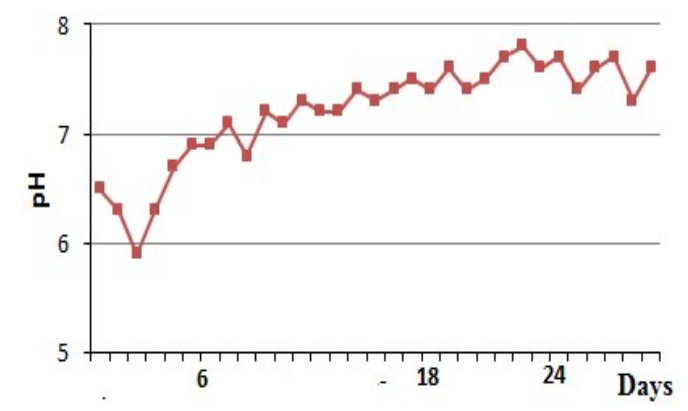

Figure 9. Experiment No. 3: $\mathrm{pH}$ variation with time.

We can appreciate that the acid phase lasted eight days after the loading of the installation. Once the $\mathrm{pH}$ was 7.1, the biogas production increased because of the methanogenic phase (Figure 10). The $\mathrm{pH}$ was stabilized at around 7.4 after 10 days.

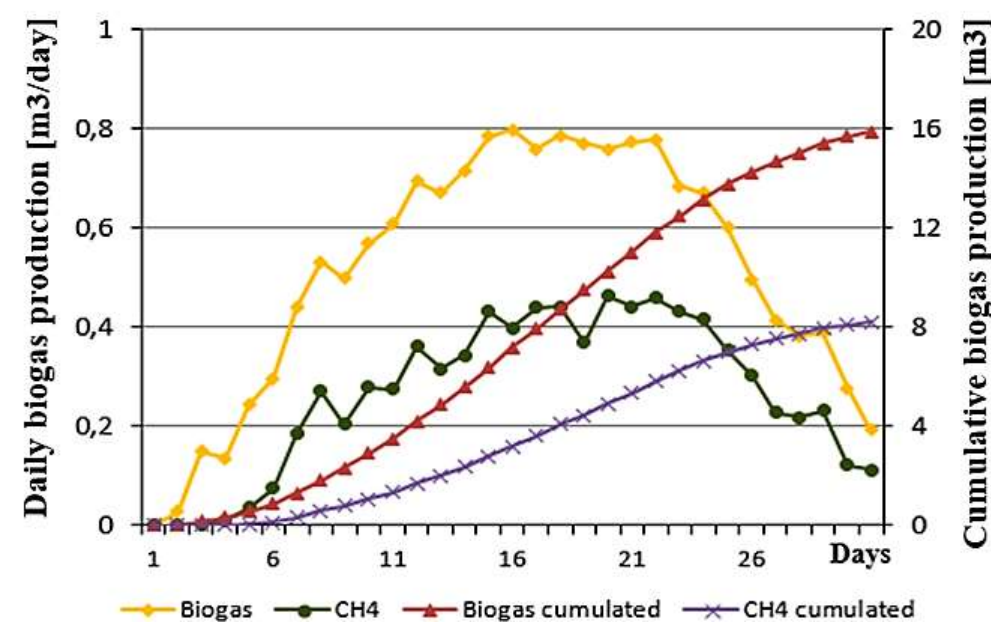

Figure 10. Experiment No. 3: daily and cumulative biogas and $\mathrm{CH}_{4}$ production. 
In the first 12 days, the $\mathrm{CH}_{4}$ and biogas production reached $0.36 \mathrm{~m}^{3}$ per day and $0.693 \mathrm{~m}^{3}$ per day, respectively. The highest rate of $\mathrm{CH}_{4}$ and biogas production was achieved between days 12-25, oscillating from 0.693 to $0.786 \mathrm{~m}^{3}$ per day. In this period of time, the average daily production of $\mathrm{CH}_{4}$ and biogas was $0.405 \mathrm{~m}^{3}$ and $0.732 \mathrm{~m}^{3}$, respectively. The maximum $\mathrm{CH}_{4}$ production of $0.463 \mathrm{~m}^{3}$ was reached by day 20. From day 24 until the end of the experiment period, the $\mathrm{CH}_{4}$ production began to decline gradually. This can be explained by the fact that the vegetable and fruit waste from the substrate had a high degree of degradability and the animal manure contributed to the degradation of the OFMSW.

The cumulative production of $\mathrm{CH}_{4}$ by day 31 of the experiment was of about $8.21 \mathrm{~m}^{3} \mathrm{CH}_{4}$. The specific biogas production related to the VS, based on Table 1 , was of about $0.334 \mathrm{~m}^{3}$ biogas $/ \mathrm{kg}_{-} \mathrm{VS}$ $\left(0.173 \mathrm{~m}^{3} \mathrm{CH}_{4} / \mathrm{kg}_{\text {-VS }}\right)$.

These values are comparable to the data from different past scientific research. Thus, the studies of Pavi et al. [21] showed that the specific production of biogas from the anaerobic co-digestion of the OFMSW with vegetables and fruit wastes was between $0.20-0.42 \mathrm{~m}^{3} / \mathrm{kg}_{-} \mathrm{VS}$ at mesophilic conditions. Also, Gashaw [19] demonstrated that the specific biogas production of the OFMSW in co-digestion with animal manure was $0.34 \mathrm{~m}^{3} / \mathrm{kg}$-vS at a ratio of OFMSW: animal manure of $50 \%$ at $55{ }^{\circ} \mathrm{C}$ and HRT of six weeks.

We can observe that the use of the animal manure contributed to a more stable methanogenesis phase with a lower variation of the $\mathrm{pH}$ value. Also, the degradability degree of the substrate was substantially improved.

In Figure 11, the average cumulative biogas yields measured from mono-digestion of OFMSW with inoculum and co-digestion of OFMSW with FVW and animal manure are displayed.

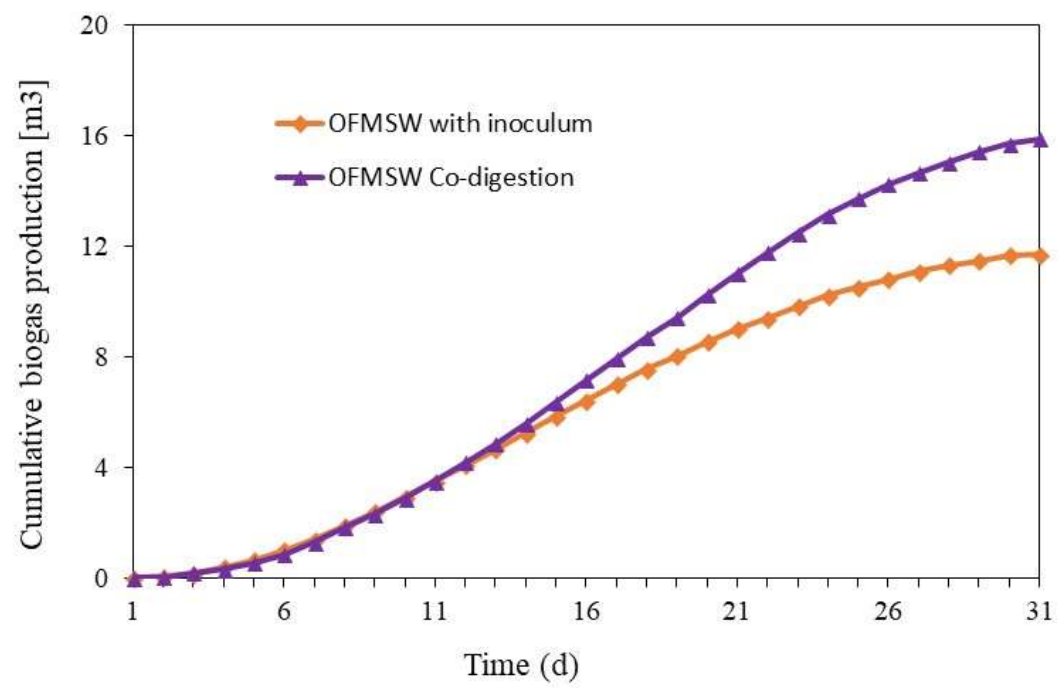

Figure 11. Average cumulative biogas yields of mono and co-digestion of OFMSW.

The cumulative biogas yield by day 31 of the experiment was of about $15.89 \mathrm{~m}^{3}$ biogas in the case of co-digestion, while for mono-digestion of OFMSW it was $11.7 \mathrm{~m}^{3}$ biogas, which is an increase of $26 \%$. In the case of co-digestion, the biogas cumulative production was higher, which had been expected seeing that the hydrolysis and the alcoholic fermentation of fruits and vegetables takes place at a much higher speed than the other organic substrates [30,34,35]. The mono-digestion resulted in an average cumulative biogas production lower than the co-digestion, but in every condition, the biogas production started relatively fast after feeding the reactor. This is due to the high concentration of simple carbohydrates in fruits and vegetables, which are rapidly biodegraded under anaerobic conditions $[19,30,31]$. 
The digestate characterization showed that TS and VS decreased by $22.7 \%$ and $37.6 \%$, respectively, compared to initial ones.

\subsection{Biogas Composition}

In this study, the biogas composition in terms of $\mathrm{CH}_{4}, \mathrm{CO}_{2}$, and $\mathrm{O}_{2}$ was analyzed. In Figure 11, the biogas composition variation (\% in volume) over time is presented. After two days, $\mathrm{CH}_{4}$ was identified in the gas composition, reaching up to $6 \%$. The $\mathrm{CH}_{4}$ concentration in the biogas increased rapidly over the next eight days up to $44 \%$, while the $\mathrm{pH}$ increased (Figure 12), and the $\mathrm{CO}_{2}$ concentrations decreased. The maximum $\mathrm{CH}_{4}$ concentration of $51 \%$ was recorded by day 17 . Between days 10 to 25 , the $\mathrm{CH}_{4}$ concentration oscillated between $44 \%$ and $51 \%$. This indicated that the methanogenesis phase of the AD process was stable. In this period, the average concentration of the $\mathrm{CH}_{4}$ in the biogas was $45.6 \%$. At the end of the experiment (days 26-30), the $\mathrm{CH}_{4}$ concentration began to decrease from $47 \%$ to $44 \%$. The concentration of the $\mathrm{CH}_{4}$ identified in the biogas composition was according to the values given in the specific literature (45-65\%) $[17,35,39,42]$.

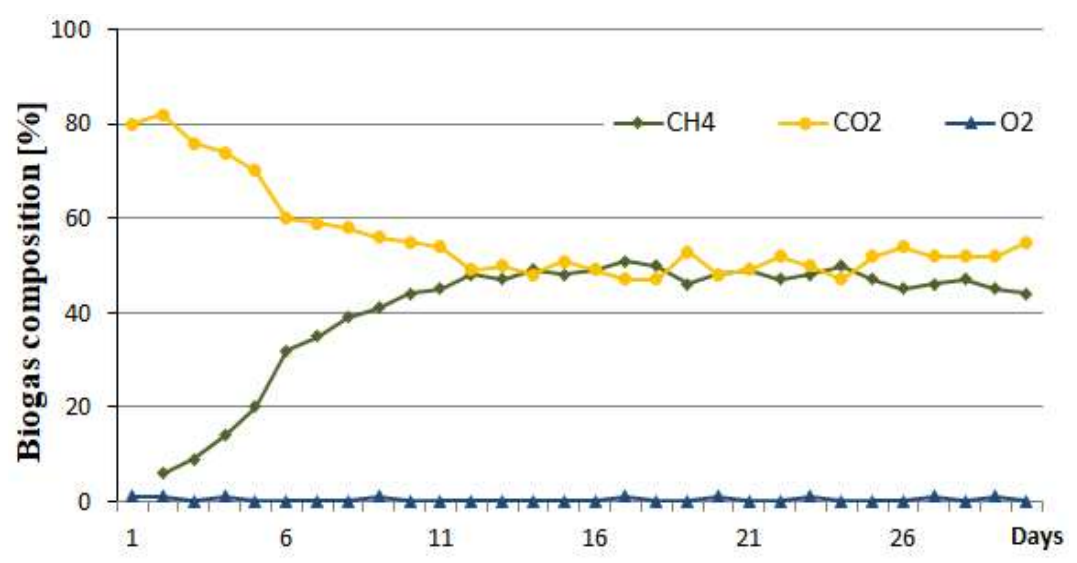

Figure 12. Experiment No. 2: Biogas composition variations over time.

Throughout the experimental work, the biogas composition varied, and the $\mathrm{H}_{2} \mathrm{~S}$ was between 150-190 ppm (parts per million). During the entire methanogenesis phase, the $\mathrm{O}_{2}$ concentration was on average of $0.25 \%$.

In the experiment with co-digestion of the OFMSW with FVW and animal manure, we observed that the $\mathrm{CH}_{4}$ concentration increased rapidly during the first 12 days reaching 52\% (Figure 13). Afterwards, from day 13 to day 31 , the $\mathrm{CH}_{4}$ concentration varied from $44 \%$ to $63 \%$. This shows that the methanogenesis phase was stable. During this period, the average $\mathrm{CH}_{4}$ content was $55.73 \%$.

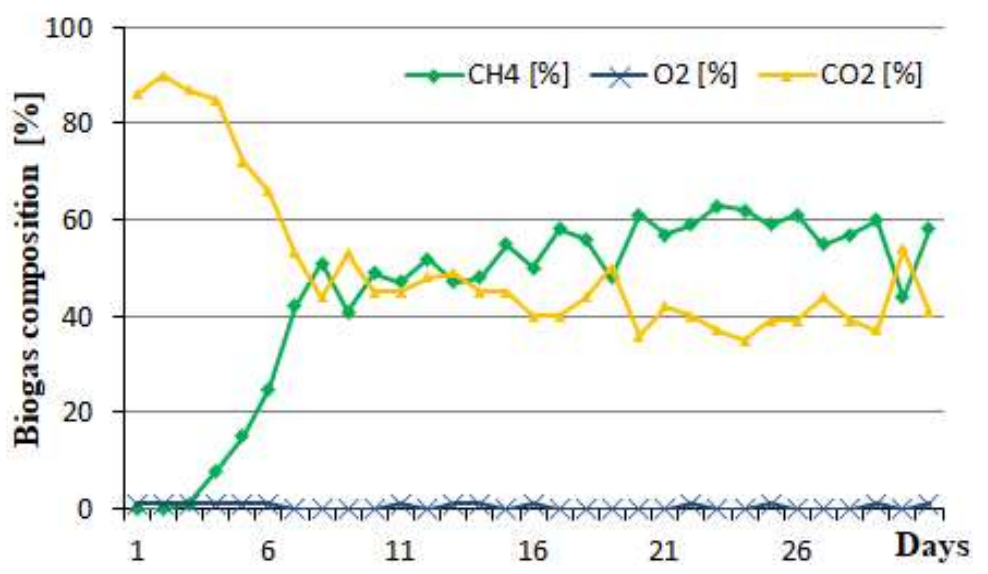

Figure 13. Experiment No. 3: Biogas composition variation over time. 
Also, the $\mathrm{CO}_{2}$ concentration in the methanogenesis phase (days 13-31) varied from $35 \%$ to $54 \%$, with an average of $42.3 \%$. In the same period, the average $\mathrm{O}_{2}$ concentration was $0.3 \%$. Comparing the results with those from the previous test, we can observe that the use of manure led to an increased $\mathrm{CH}_{4}$ concentration in the biogas composition of $10 \%$, going from about $46 \%$ to $56 \%$.

As presented in Figures 11 and 12, the average methane content of biogas produced in the pilot plant ranged between $51 \%$ and $63 \%$. The co-digestion of OFMSW and FVW resulted in higher methane content, compared with mono-digestion. This is because of the balanced supply of nutrients that contributed to an optimal living environment for anaerobic microorganisms [46].

\section{Conclusions}

This experimental study demonstrated that using co-digestion of OFMSW and FVW increased the cumulative biogas yield and the cumulative methane production compared with mono-digestion. In every experimental condition, biogas production started relatively fast after feeding, 8-10 days. This is due to the high concentration of simple carbohydrates in fruits and vegetables, which are rapidly biodegraded under anaerobic conditions. On the other hand, the use of manure as well as inoculum allowed a better methanogenesis phase stability with a lower variation of the $\mathrm{pH}$ value which contributed to a higher $\mathrm{CH}_{4}$ concentration in the biogas (from $45.6 \%$ to $55.73 \%$ ). Also, biogas production increased by about $26 \%$ compared to the AD of the OFMSW with liquid inoculum (domestic wastewater).

The anaerobic co-digestion of the OFMSW with other types of organic substrates led to the $\mathrm{AD}$ process stability and improved the biogas composition by increasing the methane concentration and biogas generation. The average daily methane production during the methanogenesis phase was $0.405 \mathrm{~m}^{3}$ compared to $0.261 \mathrm{~m}^{3}$ in the case of the OFMSW AD. At the end of the experiments, the cumulative methane production was higher by about $39 \%$, and in the co-digestion case reaching values of $8.21 \mathrm{~m}^{3}$. In this way, we illustrated how the AD practice could be improved, enhancing at the same time the biogas productivities. Additionally, from the results of the digestate analysis, we pointed out that the degradability was enhanced. Thus, the TS decreased from $19.8 \%$ to $22.7 \%$ and VS from $31.2 \%$ to $37.6 \%$.

The results obtained in this work could potentially increase the renewable energy sources in Romania and worldwide, by offering practical and appropriate options for a proper management of the OFMSW and FVW. Future developments will be focused on improving the anaerobic digestion process of OFMSW and the economic feasibility of a biogas plant. Therefore, future research will be extended in terms of: reducing HRT with environmental benefits and the optimization of the volume of the digesters; use of more efficient mechanical mixing processes; use of alkaline inoculants; improving the inoculants concentrations and the environment development for methanogenic bacteria (development of biocatalysts); and AD reactor automated control systems improvement so that this can respond to changes in process parameters ( $\mathrm{pH}$, temperature, and others). Also, future works would study the possibility of establishing the market for AD-derived products and the decrease of AD projects in terms of costs (i.e., construction and operation of $\mathrm{AD}$ plants) based on regulation in force, public policies, and tax incentives.

Author Contributions: C.S. (Constantin Stan) conceived and contributed to the writing of the paper, together with G.C. and C.S. (Constantin Streche) designed and performed the experiments. C.S. (Constantin Stan), C.S. (Constantin Streche), and T.A. contributed to the final pilot plant design. G.C. analyzed the data and optimized the process parameters. T.A. performed analysis of the data and validation of the results. D.M.C. contributed to the writing and the final design of the paper.

Funding: This work was supported by the University POLITEHNICA of Bucharest, through the "Excellence Research Grants" Program, UPB-GEX 2017. Identifier: UPB-GEX 2017, Ctr. No. 12/25.09.2017 (MODEM) and under FSE_European Structural Funds POC-A1-A1.2.3-G-2015, PROVED, ID P_40_301, My SMIS: 105707, Nb. 78/08.09.2016 (2016-2021).

Acknowledgments: The financial support by the University POLITEHNICA of Bucharest, Romania is highly acknowledged. 
Conflicts of Interest: The authors declare no conflict of interest.

\section{References}

1. International Energy Agency (IEA). Key World Energy Statistics 2017. Available online: http:/ / www.iea. org/publications/freepublications/publication/keyworld2017.pdf (accessed on 2 February 2018).

2. World Energy Council. World Energy Resources 2016. Available online: https://www.worldenergy. org/wp-content/uploads/2016/10/World-Energy-Resources-Full-report-2016.10.03.pdf (accessed on 12 December 2017).

3. Population Division, Department of Economic and Social Affairs, United Nations. World Urbanization Prospects: The 2017 Revision. Available online: https://esa.un.org/unpd/wpp/publications/Files/ WPP2017_KeyFindings.pdf (accessed on 13 December 2017).

4. Hoornweg, D.; Bhada-Tata, P. What a Waste: A Global Review of Solid Waste Management; World Bank: Washington, DC, USA, 2012.

5. United Nations Environment Programme (UNEP). Guidelines for National Waste Management Strategies: Moving from Challenges from Opportunities. Available online: http:/ /cwm.unitar.org/national-profiles/ publications/cw/wm/UNEP_UNITAR_NWMS_English.pdf (accessed on 10 November 2017).

6. Protocol on Pollutants Release and Transfer Registers. Available online: http://www.unece.org/fileadmin/ DAM/env/pp/prtr/Protocol\%20texts/PRTR_Protocol_e.pdf (accessed on 10 November 2017).

7. Decision 406/2009/EC of the European Parliament and of the Council of 23 April 2009, on the Effort Members States to Reduce Their Greenhouse Gas Emissions to Meet the Community's Greenhouse Gas Emission Reduction Commitments up to 2020. Available online: http:/ / eur-lex.europa.eu/legal-content/ EN/TXT/?uri=uriserv:OJ.L_.2009.140.01.0136.01.ENG (accessed on 12 November 2017).

8. Directive 1999/31/EC of the European Parliament and of the Council of 26 April 1999, on the Landfill of Waste. Available online: http:/ / eur-lex.europa.eu/legal-content/EN/TXT/?uri=CELEX:31999L0031 (accessed on 2 December 2017).

9. Directive 2009/28/CE of the European Parliament and of the Council of 23 April 2009, on the Promotion of the Use of Energy from Renewable Sources. Available online: http:/ / eur-lex.europa.eu/legal-content/en/ ALL/?uri=CELEX:32009L0028 (accessed on 12 January 2018).

10. Kangle, K.M.; Kore, S.V.; Kore, V.S.; Kulkarni, G.S. Recent Trends in Anaerobic Co-digestion: A Review. Univers. J. Environ. Res. Technol. 2012, 2, 210-219.

11. National Environment Agency (ANPM). Annual Report on the State of the Environment 2014, Bucharest. 2015. Available online: www.anpm.ro (accessed on 18 January 2018).

12. National Institute of Statistics and Census (INEC). Integrated System of Environmental Statistics. Available online: http:/ / www.ecuadorencifras.gob.ec/sistema-integrado-de-estadisticas-ambientales-siea/ (accessed on 24 February 2018).

13. Programa Nacional Para la Gestión Integral de Desechos Sólidos-PNGIDS ECUADOR. Available online: http:/ / www.ambiente.gob.ec/programa-pngids-ecuador/ (accessed on 2 June 2018).

14. National Waste Management Plan-PNGD ROMANIA. Available online: http://www.mmediu.ro/app/ webroot/uploads / files/2018-01-10_MO_11_bis.pdf (accessed on 2 June 2018).

15. Kumar, S.; Smith, S.R.; Fowler, G.; Velis, C.; Kumar, S.J.; Arya, S.; Rena; Kumar, R.; Cheeseman, C. Challenges and opportunities associated with waste management in India. R. Soc. Open Sci. 2017, 4, 1-11. [CrossRef] [PubMed]

16. Zakir, H.M.; Hasna, H.Q.; Uddin, M.; Ahmed, T. Municipal solid waste (MSW) as a source of renewable energy in Bangladesh: Revisited. Renew. Sustain. Energy Rev. 2014, 39, 35-41. [CrossRef]

17. Sathish, S.; Chandrasekaran, M.; Parthiban, A. Effect of co-digestion agricultural-industrial residues: Various slurry temperatures. Int. J. Ambient Energy 2017. [CrossRef]

18. Das, A.; Mondal, C. Biogas production from Co-digestion of substrates: A Review. Int. Res. J. Environ. Sci. 2016, 5, 49-57.

19. Gashaw, A. Co-digestion of municipal organic wastes with night soil and cow dung for biogas production: A Review. Afr. J. Biotechnol. 2016, 15, 32-44. [CrossRef]

20. Fernandez, J.; Perez, M.; Romero, L. Comparison of mesophifilic and thermophifilic dry anaerobic digestion of OFMSW: Kinetics Analysis. Chem. Eng. J. 2013, 232, 59-64. [CrossRef] 
21. Pavi, S.; Kramer, L.E.; Gomes, L.P.; Miranda, S. Biogas production from co-digestion of organic fraction of municipal solid waste and fruit and vegetable waste. Bioresour. Technol. 2017, 228, 362-367. [CrossRef] [PubMed]

22. Ragazzi, M.; Maniscalco, M.; Toretta, V.; Ferronato, N.; Rada, E.C. Anaerobic digestion as sustainable source of energy: A dynamic approach for improving the recovery of organic waste. Energy Procedia 2017, 119, 602-614. [CrossRef]

23. Chatterjee, B.; Mazumder, D. Anaerobic digestion for the stabilization of the organic fraction of municipal solid waste: A review. Environ. Rev. 2016, 24, 426-459. [CrossRef]

24. Ciuta, S.; Antognoni, S.; Rada, E.C.; Ragazzi, M.; Badea, A.; Cioca, L.I. Respirometric index and biogas potential for different food and agricultural discarded biomass. Sustainability 2016, 8, 1311. [CrossRef]

25. Andreottola, G.; Ragazzi, M.; Foladori, P.; Villa, R.; Langone, M.; Rada, E.C. The UNITN integrated approach for OFMSW treatment. UPB Sci. Bull. Ser. C 2012, 74, 19-26.

26. Monson, K.D.; Esteves, S.R.; Guwy, A.J.; Dinsdale, R.M. Anaerobic Digestion of Biodegradable Municipal Wastes-A Review; SERC, University of Glamorgan: Wales, UK, 2007.

27. Rapport, J.; Zhang, R.; Jenkins, B.M.; Williams, R.B. Current Anaerobic Digestion Technologies Used for Treatment of Municipal Organic Solid Waste; California Environmental Protection Agency: Sacramento, CA, USA, 2008. Available online: http:/ / www.calrecycle.ca.gov/publications/Documents/1275/2008011.pdf (accessed on 2 February 2018).

28. Deutsche Gesellschaft für Internationale Zusammenarbeit (GIZ). Guide to Biogas. From Production to Use, Federal Ministry for Economic Cooperation and Development, Germany. 2010. Available online: https: / / mediathek.fnr.de/media/downloadable/files/samples/g/u/guide_biogas_engl_2012.pdf (accessed on 5 January 2018).

29. Liotta, F.; D’Antonio, G.; Esposito, G.; Fabbricino, F.; van Hullebusch, E.D.; Lens, P.; Pirozzi, F.; Pontoni, L. Effect of total solids content on methane and volatile fatty acid production in anaerobic digestion of food waste. Waste Manag. Res. 2014, 32, 947-953. [CrossRef] [PubMed]

30. Yi, J.; Dong, B.; Jin, J.; Dai, X. Effect of Increasing Total Solids Contents on Anaerobic Digestion of Food Waste under Mesophilic Conditions: Performance and Microbial Characteristics Analysis. PLoS ONE 2014, 9, e102548. [CrossRef] [PubMed]

31. Saajena, B.B.; Jose, P.P.; Mandu, G. Effect of Total Solid Concentration of Anaerobic Digestion of the Organic Fraction of Municipal Solid Waste. Int. J. Sci. Res. Publ. 2013, 3, 1-5. Available online: http:/ /www.ijsrp.org/ research-paper-0813/ijsrp-p2068.pdf (accessed on 15 February 2018).

32. Haji, A.; Rhachi, M. The influence of particule size on the performance anaerobic digestion of municipal solid waste. Energy Procedia 2013, 36, 515-520. [CrossRef]

33. Hassan, S.R.; Zaman, N.Q.; Dahlan, I. Effect of organic loading rate on anaerobic digestion: Case study on recycled paper mill effluent using Modified Anaerobic Hybrid Baffled (MAHB) reactor. KSCE J. Civ. Eng. 2015, 19, 1271-1276. [CrossRef]

34. Chen, Y.; Rossler, B.; Zielonka, S.; Wonneberger, A.M.; Lemmer, A. Effects of Organic Loading Rate on the Performance of a Pressurized Anaerobic Filter in Two-Phase Anaerobic Digestion. Energies 2014, 7, 736-750. [CrossRef]

35. Parra-Orobio, B.A.; Torres-Lozada, P.; Marmolejo-Rebellón, L.F. Influence of the mixing ratio on the anaerobic co-digestion of municipal biowaste with domestic wastewater sludge on methane production. DYNA 2016, 83, 86-93. [CrossRef]

36. Yong, Z.; Dong, Y.; Zhang, X.; Tan, T. Anaerobic co-digestion of food waste and straw for biogas production. Renew. Energy 2015, 78, 527-530. [CrossRef]

37. Ministry of Environment. National Program for Integrated Management of Solid Waste-PNGIDS, Ecuador. Available online: http:/ / www.ambiente.gob.ec/programa-pngids-ecuador/ (accessed on 16 February 2018).

38. Dublein, D.; Steinhauser, A. Biogas from Waste and Revewable Resourses: An Introduction, Second, Revised and Expanded Ed.; Wiley-VCH: Weinheim, Germany, 2011.

39. Zhongfang, L.; Zhenya, Z.; Weiwei, H.; Wei, C. Recent Progress on Dry Anaerobic Digestion of Organic Solid Wastes: Achievements and Challenges. Curr. Org. Chem. 2015, 19, 400-412. [CrossRef]

40. Chen, G.; Liu, G.; Yan, B.; Shan, R.; Wang, J.; Li, T.; Xu, W. Experimental study of co-digestion of food waste and tall fescue for biogas production. Renew. Energy 2016, 88, 273-279. [CrossRef] 
41. Fiore, S.; Ruffino, B.; Campo, G.; Roati, C.M.C. Zanetti Scale-up evaluation of the anaerobic digestion of food-processing industrial wastes. Renew. Energy 2016, 96, 949-959. [CrossRef]

42. Adebayo, A.O.; Jekayinfa, S.O.; Linke, B. Effect of co-digestion on anaerobic digestion of pig slurry with maiz cob at mesophilic temperature. J. Natl. Sci. Res. 2014, 4, 66-73.

43. Zhu, G.; Jha, A.K. Psycrophilic dry anaerobic digestion of cow dung for methane production: Effect of inoculum. Sci. Asia 2013, 39, 500-510. [CrossRef]

44. Sovacool, B.K.; Kryman, M.; Smith, T. Scaling and commercializing mobile biogas systems in Kenya: A qualitative pilot study. Renew. Energy 2015, 76, 115-125. [CrossRef]

45. Aidan, W.; Niamh, P. Biogas from cattle slaughterhouse waste: Energy recovery towards an energy self-sufficient industry in Ireland. Renew. Energy 2016, 96, 479-489. [CrossRef]

46. Li, C.; Champagne, P.; Anderson, B.C. Enhanced biogas production from anaerobic co-digestion of municipal wastewater treatment sludge and fat, oil and grease (FOG) by a modified two-stage thermophilic digester system with selected thermo-chemical pre-treatment. Renew. Energy 2015, 83, 474-482. [CrossRef]

47. Yoon, Y.M.; Kim, S.H.; Shin, K.S.; Kim, C.H. Effects of Substrate to Inoculum Ratio on the Biochemical Methane Potential of Piggery Slaughterhouse Wastes. Asian-Australas J. Anim. Sci. 2014, 27, 600-607. [CrossRef] [PubMed]

48. Directive 2008/98/CE of the European Parliament and of the Council of 19 November 2008 on Waste and Repealing Certain Directives. Off. J. Eur. Union 2008, L 312, 3-30. Available online: http:/ / data.europa.eu/ eli/dir/2008/98/oj (accessed on 2 June 2018).

49. Kheiredine, B.; Derbal, K.; Mossaab, B.-L. Effect of inoculum to substrate ratio on termophilic anaerobic digestion of the dairy wastewater. Chem. Eng. Trans. 2014, 37, 865-870. [CrossRef]

50. Hou, L.; Ji, D.; Zang, L. Inhibition of anaerobic biological treatment: A review. IOP Conf. Ser. Earth Environ. Sci. 2018, 112. [CrossRef]

51. Achinas, S.; Achinas, V.; Euverink, G. A technological overview of biogas production from biowaste. Engineering 2017, 3, 299-307. [CrossRef]

52. Huang, X.; Yun, S.; Zhu, J.; Du, T.; Zhang, C.; Li, X. Mesophilic anaerobic codigestion of aloe peel waste with dairy manure in the batch digester: Focusing on mixing ratios and digestate stability. Bioresour. Technol. 2016, 218, 62-68. [CrossRef] [PubMed]

53. Ventorino, V.; Romano, I.; Pagliano, G.; Robertiello, A.; Pepe, O. Pre-treatment and inoculum affect the microbial community structure and enhance the biogas reactor performance in a pilot-scale biodigestion of municipal solid waste. Waste Manag. 2018, 73, 69-77. [CrossRef] [PubMed]

54. Li, D.; Yuan, Z.; Sun, Y. Semi-dry mesophilic anaerobic digestion of water sorted organic fraction of municipal solid waste (WS-OFMSW). Bioresour. Technol. 2010, 101, 2722-2728. [CrossRef]

55. Mao, C.; Feng, Y.; Wang, X.; Ren, G. Review on research achievements of biogas from anaerobic digestion. Renew. Sustain. Energy Rev. 2015, 45, 540-550. [CrossRef]

56. Velmurugan, B.R.; Ramanujan, A. Anaerobic digestion of vegetable wastes for biogas production in a fed-batch reactor. Int. J. Emerg. Sci. 2011, 1, 478-486.

57. Forster-Carneiro, T.; Pérez, M.; Romero, L.I. Anaerobic digestion of municipal solid waste: Dry thermophilic performance. Bioresour. Technol. 2008, 99, 8180-8184. [CrossRef] [PubMed]

(C) 2018 by the authors. Licensee MDPI, Basel, Switzerland. This article is an open access article distributed under the terms and conditions of the Creative Commons Attribution (CC BY) license (http://creativecommons.org/licenses/by/4.0/). 